Memorial Laboratory. Prof. W. H. Davies, of the University of Wales, was presented with a plaque for the laboratories at Aberystwyth, from which Soddy gained a scholarship to Merton College, Oxford. A larger plaque, commemorating the work done by Soddy in collaboration with Rutherford during $1900-3$, which led to the discovery of transmutation, interpreted by Soddy as the disintegration of the atom, was on show and will be sent to McGill University to be set up in the chemistry laboratory.

\section{Organization for European Economic Co-operation:} Office of Scientific and Technical Man-power

A special Office of Scientific and Technical Manpower has been set up within the Organization for European Economic Co-operation to direct its drive for increasing the supply of qualified scientists and engineers needed to meet the growing demand of the industries of Europe. Dr. Alexander King, while continuing as deputy director of the European Productivity Agency, has been appointed director of the new Office, responsible to the Secretary-General of the Organization for European Economic Cooperation. The scientific man-power programme will be under the direction of a governing committee composed of representatives of seventeen European States, the United States and Canada. The Organization has already initiated several projects in this field which will now come under the direction of the new Office. These include an annual review of the policies and programmes of member countries for the training of scientists and engineers; a study of techniques for forecasting demand for scientific and technical personnel and a series of summer training courses for science and mathematics teachers. Funds for this programme and other projects will come from an allocation of 500,000 dollars by the United States Government, together with an initial contribution by the member countries of the Organization and special additional contributions as further projects are approved by the governing committee.

\section{New Nature Reserves}

RusLand Moss is one of the few remaining examples in the southern Lake District of a 'moss' which has not been damaged beyond repair. It is a raised bog only $20 \mathrm{ft}$. above sea-level which originated in a lake. Although partly cut and drained, it still retains most of the characteristic bog plants and animals. The reserve, which has been established under a Nature Reserve agreement with the owner, Judge Myles Archibald, covers 30 acres. The Moss is about 4 miles north of Roudsea Wood Nature Reserve, Lancashire, and is conveniently near the Nature Conservancy's main research station at Grange-over-Sands. Permits, which will be necessary for those wishing to visit or collect specimens of animals or plants, can be obtained from the Regional Officer for the North, The Nature Conservancy, Merlewood Research Station, Grange-over-Sands, Lancashire.

In June 1957 the Nature Conservancy established the Rodney Stoke Nature Reserve, a small ash wood on the Mendip Hills near Cheddar in Somerset. Two small further areas have now been added, bringing in the smaller western wood and some scrubland, thus completing the reserve, which now covers an area of 86 acres. The western wood contains an outcrop of Carboniferous limestone, and there are interesting differences in the flowering plants on the south-western and north-eastern sides of this out- crop. Applications for permits to visit the reserve and for authority to undertake research and to collect specimens of animals and plants should be sent to the Regional Officer for the South West, The Nature Conservancy, Furzebrook Research Station, Wareham, Dorset.

\section{Industrial Smoke}

There was a debate in the House of Commons on May 13 and 14 on a motion of Mr. G. Nabarro's, seconded by Sir Charles Taylor, praying for the annulment of the Alkali, etc., Works Order, 1958, which seeks to transfer from the local authorities to the Alkali Inspectorate the responsibility for discharges from industrial chimneys in certain industries. The Minister of Housing and Local Government, Mr. H. Brooke, said that the Order was a statutory instrument made under the Public Health (Smoke Abatement) Act, 1926, the first to be made since the extension to smoke, grit and dust was approved in the Clean Air Act, 1956. It arose out of a specific recommendation of the Beaver Committee, and was not intended to give the industries specific protection from any action taken by authorities but to enable certain special technical difficulties to be tackled by a single inspectorate with special technical qualifications, reviewing each industry as a whole. The trouble was due not to unskilled or careless operation but to the fact that scientific research had not yet solved the problem of operating the particular plant without risk of produeing dark smoke. The Order would apply to about 2,000 works out of a total of 25,000-30,000 throughout Britain, and does not deprive local authorities of powers which they have hitherto effectively possessed. $\mathrm{He}$ assured the House that he would use his powers so that the Alkali Inspectorate had every opportunity of stimulating the necessary scientific research, and wherever a local authority is well qualified to take over the work an Order will be made to enable it to do so. So long as he was Minister, the relevant Section 17 (2) of the Clean Air Act would not be treated as a dead letter and he intended to treat any such application on its own merits. Mr. Brooke was satisfied as to the effectiveness of the Alkali Inspectorate and in view of his explanation and assurance the motion was withdrawn.

\section{The Opticians Bill}

THE Opticians Bill, which received an unopposed second reading in the House of Lords on May 12, has the support of all ophthalmic practitioners, and although not a Government Bill, was commended to the House by the Minister of State, Scottish Office, Lord Strathclyde, who said that the Government is satisfied that the Bill is in the general interest of the health and well-being of the people, while safeguarding the right of practitioners affected by it and maintaining and raising professional standards. In moving the second reading, Lord Amherst of Hackney explained that the Bill followed closely the recommendations of the intendepartmental committee set up in 1949 under Lord Crook's chairmanship. It would set up a General Optical Council to promote high standards of professional education and conduct, charged with the establishment of the three registers : two of ophthalmic opticians and one of dispensing opticians. The first register would comprise those who merely test sight; the second those who test and dispense glasses; and the third of dispensing opticians. Lord Crook, in supporting the Bill, explained some of the ways in which existing abuses 